\title{
Why A. Smith Might Have Been Right, After All
}

\author{
Mario De Marchi \\ CNR-IRCRES, Consiglio Nazionale Delle Ricerche, Istituto di Ricerca Sulla Crescita Economica Sostenibile, Roma, Italy \\ Email: mario.demarchi@hotmail.com
}

How to cite this paper: De Marchi, M. (2019) Why A. Smith Might Have Been Right, After All. American Journal of Industrial and Business Management, 9 , 1980-1982.

https://doi.org/10.4236/ajibm.2019.911129

Received: October 4, 2019

Accepted: November 16, 2019

Published: November 19, 2019

Copyright $\odot 2019$ by author(s) and Scientific Research Publishing Inc. This work is licensed under the Creative Commons Attribution International License (CC BY 4.0).

http://creativecommons.org/licenses/by/4.0/

\begin{abstract}
An attempt is made here at proving a controversial intuition: real profits may be determined by prices not by wages.
\end{abstract}

\section{Keywords}

Methodology of Economics, Theory of Prices and Income Distribution

\section{Introduction}

In theories following, the classical economic approach, the prices of commodities and the income distribution are closely linked. Indeed, David Ricardo, Karl Marx and Piero Sraffa, all devised methods for the determination of prices founded on assumptions of given income distribution, either equating values of commodities to labour (directly and indirectly) incorporated in them or working out relative prices as the results of simultaneous equations representing the productive conditions of the industries making up an economic system. In fact, we argue that perhaps an opposite logical choice may be made, assuming the rate profit as the effect and the level of prices as the cause.

\section{Reducing Prices into Incomes}

An insurmountable hurdle to this way of thinking is usually referred to as the circular reasoning which would apparently follow from the fact that prices, on their turn, usually depend on the rate of profit. As far as it may go, the attempt to sever the nexus between prices and distribution by entirely breaking down the price of a commodity into wages and profits, paid during the last and the previous production periods to realize it, would not almost ever reach the end: a residual of means of production will usually be leftover. So, the loop among distribution and prices seems impossible to be cut by taking the level of prices as the given circumstance. 


\section{Getting around the Obstacle}

However, in a fundamental case, such obstacle can be overcome, and the alternative path can be followed, by taking as the independent variable a peculiar price, the one of the "Standard Commodity", the ingenuous analytical tool Sraffa [1] devised as an ideal measure of all prices, those of commodities and the price of labour, wage. Using this instrument he followed the opposite logical path that is undertaken here: Sraffa, as Ricardo is supposed to have done before him, trunked the loop between rate of profit and prices by eliminating the last ones. The essential feature of the Standard Commodity is the recursivity in the ratio of product over its previous layer of means of production. And it is just this characteristic which allows us to reduce fully such commodity's price by a finite logical and mathematical process.

\section{Completing One Price Reduction}

Now we make the hypotheses that (a) wages be paid post factum; and (b) the " $V$ " value of the Standard Commodity is gauged by the quantity of labour it can pay for (i.e. by the labour it "commands", in the wording of Adam Smith). Then, in Equation (1) below, " $V$ " is worked out as the limit of a sum, defined by a geometrical series, where " $r$ " is the rate of profit and " $1+R$ " is the proportion between product and means of production:

$$
V=w((1+r) /(1+R))^{0}+\cdots+w((1+r) /(1+R))^{n}+\cdots
$$

when " $n$ " tends to the infinity.

\section{Determining the Rate of Profit after the Level of Prices}

As a consequence, we might as well assume that the bargaining between entrepreneurs and workers will determine wages (as suggested by John Maynard Keynes [2]). But our final equation entails that if we take as given: $R$, incorporating the technology (as Sraffa does), and $V$, reflecting a level of effectual demand (as Keynes implies): then, the rate of profit will depend on an amount of labour commanded (as Smith argues [3]). This will happen according to the relationship:

$$
(1+R) /(R-r)=V / w
$$

whereby: if, say, " $V$ " increased from the minimum, viable level " $(1+R) / R$ " towards the infinity, then " $r$ " would grow from zero to the maximum " $R$ ".

\section{Conflicts of Interest}

The author declares no conflicts of interest regarding the publication of this paper.

\section{References}

[1] Sraffa, P. (1960) Production of Commodities by Means of Commodities, Cambridge University Press, Cambridge. 
[2] Keynes, J.M. (1936) The General Theory of Employment, Interest and Money, Palgrave Macmillan, London.

[3] Smith, A. (1776) The Wealth of Nations, W. Strahan and T. Cadell, London. 